State Policy and the Yeoman Ideal: Agricultural Development in Western

Australia, 1890-1914

Matthew Tonts

Department of Geography

University of Western Australia

35 Stirling Hwy

Crawley, 6009, Western Australia

Australia

Submitted to Landscape Research, May 2001 


\begin{abstract}
This paper examines the significance of the 'yeoman ideal' in the formulation of Western Australian agricultural development policy between 1890 and 1914 . It argues that the Colonial and, later, State governments of Western Australia not only regarded themselves as the promoters of economic development, but also as the architects of a desired cultural landscape and social class. This was reflected in numerous government reports, legislation and advertising that emphasised the virtues of small-scale family owned and operated yeoman farms. The paper points out that, despite the serious ongoing environmental and economic difficulties facing this type of farming, the state remained captivated by the yeoman ideal until at least the onset of the First World War.
\end{abstract}




\section{State Policy and the Yeoman Ideal: Agricultural Development in Western Australia, 1890-1914}

One of the features of early capitalist development in Australia and New Zealand was the significant role of the state in the management of economic resources. Much of the research on this subject highlights the failure of private enterprise to stimulate substantial levels of economic activity, immigration and infrastructure development in the fledgling colonies (see Battye, 1924; Eggleston, 1932; Powell, 1988a). In response to the problem of underdevelopment, colonial governments invested heavily in social and economic overheads as a means of 'pump priming' local economies and promoting the viability of private enterprise. The construction of railways and port facilities, the establishment of development banks, immigration programs, and the provision of subsidised agricultural land to new settlers were strategies widely adopted by governments to help encourage economic development.

While considerable attention has been paid to understanding the economic rationale and outcomes of heavy state investment in agricultural development (see Metin, 1901; Roberts, 1924; Bolton, 1972; McMichael, 1984), comparatively little research has dealt with the cultural and landscape aspirations of government policy in Australia. This is despite considerable evidence to suggest that the agricultural development policy was driven, at least in part, by the pursuit of a fabled 'yeoman ideal' (Powell, 1988b). The purpose of this paper is to examine the significance of this yeoman ideal in the formulation of agricultural development policy in Western Australia in the 
years following the granting of self government in 1891. It points out that, although the central goal of state assistance to agriculture was the promotion of economic development, policy-makers were also captivated by romantic notions of "settling a bold peasantry on the soil" (Forrest, quoted in PDWA, 1886, p. 96). In many respects, the state not only regarded itself as the promoter of economic development, but also as the architect of a desired cultural landscape and social class. The paper begins by providing a brief overview of early agricultural development policy in Western Australia, before examining a range of government reports and legislation that aimed to foster the development of yeoman farming between 1891 and the onset of the First World War.

\section{Early Agricultural Development in Western Australia}

In 1829, Western Australia (the Swan River Colony) was established as the third colony in Australia, largely in response to a favourable report on the region's agricultural potential by Captain James Stirling (see Crowley, 1960). While the development of agriculture became one of the main objectives of early colonial policy, it soon became apparent that, contrary to Stirling's report, the Swan River region was not characterised by the "richness of the soil" (Stirling, quoted in Commonwealth of Australia, 1921, p.588) that was "capable of producing any crop" (Fraser, quoted in Commonwealth of Australia, 1921, p.581). Indeed, one London newspaper observed that "instead of the land about the coast being a sort of Paradise, it is, for the most part, little better than a barren waste" (The Herald, 28/1/1830). Similarly, an early settler in the Swan River Colony commented that "the soil is such that no human being can possibly exist" (quoted in Cameron, 1975, p.166). The 
subsequent lack of agricultural progress in the Colony became a feature of the next half century as various attempts to develop small-scale farming systems were attempted and failed. Perhaps the most spectacular failure was that of Thomas Peel who, in 1829 , was granted 250,000 acres of land south of Perth on which to promote small-scale family farming (Battye, 1924)(see Figure 1). Under Peel's scheme, immigrants were offered land in proportion to the value of the equipment and stock they brought to the Colony. All grants were made on the condition that unless the land was improved (i.e. cleared and, importantly, cultivated) within 10 years it would be resumed by the Colonial Office. While Peel's settlement scheme generated considerable initial interest, a combination of poor soils, harsh climatic conditions, the high cost of developing services and infrastructure, and managerial incompetence saw the last settlers abandon the estate in 1839 (see Hasluck, 1965).

\section{Insert Figure 1 About Here}

Despite the failure of the Peel scheme, Western Australia's colonial administrators were determined to pursue the development of an agricultural landscape reminiscent of that in Europe (Cameron, 1981). As Powell (1988b) points out, the most important characteristics of this landscape were that farms be freehold properties, family operated and cultivated. Thus, the colonial administration granted small holdings, often less than 50 acres in size, to prospective farmers and, as further incentive to establish intensive agriculture, operated a scheme under which the state agreed to purchase all wheat grown in the colony for a guaranteed fixed price. The Colonial administrators also turned to the ideas of Edward Gibbon Wakefield, who argued that if land in the colony was sold at a price sufficient to ensure that only middle class 
could afford to purchase land, and if the revenue from the sales of land were used to subsidise labour immigration, then a system of agriculture and rural settlement similar to that in England would emerge (Cameron, 1981).

One of the most notable examples of Wakefieldian 'systematic colonisation' in the Swan River Colony was the Western Australian Company's Australind project. The Western Australian Company was formed in 1840 and granted 100,000 acres near the town of Bunbury, 200 kilometres south of Perth (Cameron, 1975). The estate was divided into a series of 100 acre farms and the land sold for 1 Pound an acre. A portion of the proceeds were put into an emigration fund to help pay for the passage of workmen and their families. However, as with the Peel scheme, the high cost of land, the difficult environmental conditions, the small size of the blocks, and the absence of a sizable local commodity market made farming extremely difficult. Most of the immigrant workers left the area in search of employment elsewhere, while the remaining landowners struggled to remain viable.

Despite the colonial administrators' ongoing desire for intensive agriculture and rural settlement, the reality was that the most successful form of primary production in the colony was the extensive sheep grazing industry, which occupied pastoral leases in those regions deemed too remote to establish intensive farming (Burvill, 1979). While the arrival of around 10,000 convicts between 1850 and 1868 stimulated a degree of agricultural expansion, the end of convict transportation was followed by around 15 years of economic hardship. By the late 1870s, the Colonial administration had become convinced that the inaccessibility of the areas with agricultural potential was the main factor restricting the development of small-scale farming, and that the 
provision of a network of railways would improve the efficiency and viability of this form of agriculture.

In eastern Australia, colonial governments had constructed and operated railways in agricultural areas on an extensive scale since the mid-1840s (McMichael, 1984). In Western Australia, however, railway development had been constrained by the relatively narrow taxation and public revenue base, the long distances involved, and the low levels of economic and population growth. Nevertheless, in 1879, the Colony's Legislative Council approved the construction of a railway linking Perth and the Avon Valley; an intensive agricultural region developed during the convict period. Even before the completion of this railway in 1888 there were widespread public criticisms of the project, largely on the grounds that, although it had helped to consolidate an important existing agricultural region, it did little to promote the expansion of farming into new areas (Battye, 1924). Furthermore, there were concerns that the railway had contributed to an over-extension of public debt (Glynn, 1975). In response to these problems, the Colonial government turned to the system of making free grants of land, which had been widely adopted in Canada and the United States (see Hibbard, 1939; Benedict, 1953). The government argued that this system of development could lead to substantial increases in intensive agriculture with minimal strain being placed on the government's limited borrowing capacity.

In September 1881, the Colonial government called for tenders to construct a land grant railway between the Avon Valley and the southern port settlement of Albany. The contract to construct the line was awarded to the Western Australian Land Company in October 1884. This London based syndicate received a land grant of 1.2 
million hectares in return for building 389 kilometres of track and settling 50,000 new European migrants on small farms adjacent to the railway (Bolton, 1958). However, after the death of the Company's director, Anthony Horden, in 1886, the project fell into the hands of absentee investors who showed little interest in his ambitious settlement schemes. Furthermore, the difficulties in securing agricultural land sales and in attracting immigrants dramatically reduced profit expectations. Despite this, construction of the railway continued and, in 1889, the Great Southern Railway was opened.

Similar problems were faced by the Colony's only other land grant railway, linking York and Geraldton, which, from the outset, faced difficulties in raising capital, attracting and settling migrants, and achieving profits (Glynn, 1966). The combined effects of these problems resulted in the line being not being completed until 1894, ten years after the original proposals had been accepted and eight years after construction commenced. Such was the frustration at the failure of the land grant system of agricultural development that there was a growing consensus among many of the Colony's leaders that the state should take a more active role in promoting the expansion of small scale farming.

\section{The Royal Commission on Agriculture, 1887-1891}

The difficulties facing agriculture in the Colony were the subject of a Royal Commission between 1887 and 1891. The final report of the Commission attributed the slow progress of agricultural development to relatively depressed commodity markets and the lack of incentives for new settlers to enter the industry. The 
Commission's report has been widely interpreted as a watershed in agricultural development policy. For Glynn (1975), the report later formed the basis of a pragmatic government response to the problem of stagnation in the agricultural sector (see also Burvill, 1979). However, it is also clear that the authors of the report were captivated by romantic notions of small-scale yeoman farmers. This was despite mounting evidence to indicate that low rainfall, poor soils and noxious weeds presented serious environmental limitations to small cultivated farms in Western Australia (Crowley, 1960). Indeed, it was still the more extensive wool industry that was the most successful form of agriculture in the Colony, contributing 77 per cent of exports in 1889 (Appleyard, 1981). Nevertheless, the Commission's commitment to the establishment of an agricultural landscape based on small freehold mixed enterprise farms was reflected in the report's recommendations, and in subsequent policy decisions. Such was the importance of this social and landscape ideal that the Commission (1891, p.13) argued that "the object and desire of every good government should be the permanent settlement of the Colony by a yeoman class on lands yielding each its special product according to its capabilities and its uses". The report of the Commission also provides important insights into what were regarded as the inherent qualities of those individuals engaged in small scale agriculture, suggesting that:

"...the advocations of a farmer call forth all the best qualities that a man should be gifted with: business capacity, diligent attention to duties, observant in small matters, quick at expedient, combined with a sound sense, and a practical knowledge of the laws of growth and fertilisation" (Commission on Agriculture, 1891, p.16).

As Powell (1988b) has discussed in the context of Australia's eastern colonies, these images pervaded much government debate during the 1890s, and reinforced the mythical qualities of yeoman farmers, including their self reliance and a strong sense 
of nationalism (see also Hirst, 1992). These virtues were elaborated further in the Commission's report, particularly in relation to concerns about the high cost of credit in the Colony and its impact on individuals farmers:

The question of borrowing sits very much like a nightmare on the mind of a farmer of the yeoman class, and he prefers the freedom which to him surrounds a life of self reliance... Self reliance is so strongly interwoven with his daily advocations as to become an individuality of the class, and a mortgaged property seems to rob them of that motive power which should stimulate their energy (Commission on Agriculture, 1891, p. 12).

The Commission goes on to suggest that the provision of cheap credit by the Colonial government would help to ensure the viability of the yeoman farming system. The concerns about the impacts of borrowing on farmers appears to have emerged as a result of the financial difficulties facing many smaller farmers in the Colony during the 1880s and early 1890s (see Crowley, 1960). A combination of poor commodity prices, high input costs and the absence of economies of scale saw many farmers borrow heavily from commercial lenders to expand their holdings. While government rhetoric suggested that farms of less than 100 acres could be profitable, in reality the Colony's environmental conditions meant that only larger farms were able to remain profitable in the longer term (Battye, 1924). Despite this, the Commission argued strongly in favour of small scale farming, suggesting:

"there is, in the opinion of the Commission, a desire, generally, on the part of those taking up land, to take too much. A more fatal mistake can hardly be made by the farmer than to have too much land... Small areas, in a high state of cultivation, and within the grasp of individuals, is one of the chief elements of success in farming" (Commission on Agriculture, 1891, p. 16).

Thus, the Commission did not simply prescribe the virtuous the socio-cultural characteristics of the yeoman farmer, but also the physical characteristics of the agricultural landscape. Indeed, the report went further and provided detailed insights into what it regarded as an appropriate mix of on-farm enterprises, inducing romantic 
notions of families producing crops and livestock for both cash income and home consumption:

"Wheat may, or should be, a primary factor of their business, but the production of oats, barley, and hay should always form a large portion of their income. During the winter months a large and profitable addition to the income should be made by curing bacon and hams. No farm should be without a few sheep; they not only furnish the family with a cheap food supply, but manure the soil and assist to clear the land from weeds. Attention to garden produce should not be lost sight of, as throughout these areas general garden produce can be raised in large quantities, and, where there is no market for it, it cheapens the food supply of the farms, and is valuable as pig fodder" (Commission on Agriculture, 1891, p. 7).

The importance of the yeoman ideal as a policy objective was further emphasised by the Commission's recommendation that the Colonial government adopt a series of measures to "advance the cultivation of the soil" $(1891$, p. 1). The more detailed recommendations included the provision of low cost loans to farmers, the provision of small parcels of subsidised land to new settlers, the establishment of agricultural schools, assisted migration, and the repurchase of vacant agricultural land held by absentee investors.

\section{State Sponsored Agricultural Development}

The recommendations of the Commission were generally in tune with the sensibilities of the key political leaders in Western Australia at the time, particularly the Colony's first Premier, Sir John Forrest. Forrest was the son of Scottish immigrant William Forrest, who took up a small property on the Wakefieldian inspired Australind scheme. Prior to his election as Premier in 1891, John Forrest had been the Colony's Surveyor General and was a strong advocate of development of small-scale farming. Indeed, in his second annual Report on Crown Lands and Surveys (Votes and 
Proceedings of the Legislative Council, 1884), Forrest favoured a concentration of farming population in the fashion advocated by E. G. Wakefield and used as the basis for the failed Australind scheme. He had also been an active supporter of both of the Colony's land grant railways. However, by the 1890 s Forrest, like many Western Australians, had become frustrated by the failure of private enterprise to stimulate small-scale agricultural development. In a speech made in 1896 Forrest commented:

If there is one thing more than another that has been proved to the satisfaction of all of us, in regard to these English companies which undertake the settlement of land in this Colony, it is that they seem unable to develop the lands which they hold here. I think their land settlement has been a complete failure... these lessons have taught us to be very careful in handing over great enterprise to private individuals (Parliamentary Debates of Western Australia, 1896, p. 691).

Given Forrest's commitment to intensive agriculture, and his growing conviction that direct state intervention was an appropriate means of stimulating agricultural development, it is perhaps not surprising that he adopted most of the 1891 Commission on Agriculture's key recommendations.

The first of these was the parliamentary approval of the Homesteads Act, 1893. This Act entitled any person, not already the owner of the more than 100 acres of agricultural land, to a free homestead farm not exceeding 160 acres. The main condition of the grant was that the settler adhere to a strict seven year improvement timetable, as well as a regular inspection to ensure that the property was being actively farmed (and, in particular, cultivated). While the basic objective of the Act was to stimulate economic development, there is also considerable evidence to suggest that the pursuit of the yeoman ideal was an important consideration. The Parliamentary Debates of Western Australia for 1893 (p. 230) indicate that the government's aim was to establish "a bold peasantry, their country's pride, men of 
small means but strong arms and stout hearts". The Act also drew heavily from similar legislation in the United States (the 1862 Homestead Act), where the virtues of yeoman farming were highly celebrated (Paarlberg, 1964; Fite, 1981; Cochrane, 1993). In debating the 1893 Act, Sir John Forrest was a particularly strong advocate of yeoman farming:

"What does a man come away from the old country for? Not only to better his position in a new land, but to obtain himself a freehold on which he can found a home... I am aware that some persons laugh at the idea of us having a race of peasant proprietors. They seem to have received the suggestion as a good joke, when I spoke about a bold peasantry. But the expression is a good one, and I am a great believer in a peasant proprietary - I mean people living on small areas of land and possessing them as their freeholds" (quoted in Crowley, 2000, p.126).

Despite the widespread enthusiasm for the Homesteads Act, it was not without its critics. Indeed, many felt that it failed to recognise the environmental and economic limitations of small farms (Cooper, 1975). There were also those who argued that the state should not have a direct hand in promoting economic development, and that land was a precious resource which should not be offered to "an impecunious lot of... 'pauper lunatics"' (quoted in Crowley, 2000, p.126).

The Homesteads Act was complimented by the introduction of the Agricultural Bank Act, 1894. This was a direct response to the Royal Commission on Agriculture's concern that the interest rates on credit provided by commercial lenders was too high for most small farmers. The Act provided the basis for the establishment of the Agricultural Bank of Western Australia, which made loans to farmers for clearing and cultivating the land. The maximum amount available to successful applicants was A£400. Interest was not to exceed six per cent per annum, with borrowers expected to start repaying the principal after five years. The Bank's main objective was to 
provide farmers with a sound financial footing during the early pioneering stages of agricultural development.

In addition to financing agricultural development, the government also attempted to protect the expanding industry from intercolonial and overseas competition through amendments to the Tariff Act, 1888 (amended 1893), which increased import duties on livestock and grain. Furthermore, and as recommended in the 1891 Royal Commission's report, the Forrest government established a Bureau of Agriculture to help improve the scientific basis of farming in Western Australia. The Bureau became the Department of Agriculture in 1898 and, as well as providing technical and scientific advice to farmers, it advised the government on aspects of agricultural policy, published a regular journal of agriculture, and established a number of research farms.

\section{The Gold Rush and Agricultural Development}

One of the reasons that the Colonial government was able to invest heavily in schemes such as the Homesteads Act, the Agricultural Bank and the Department of Agriculture was its stronger financial position following the discovery of gold in Western Australia during the early 1890s. The largest deposits were found at Coolgardie (1892) and Kalgoorlie (1893). These proved to be an economic watershed for the Colony, and between 1890 and 1900 Western Australia's population increased from 48,502 to 179,258; a rise of 131,465, or 271 percent (Appleyard, 1981). Thus, at a time when economic conditions in the eastern Australian colonies were deteriorating in the aftermath of the New South Wales and Victorian gold rushes, and as the value 
of wheat and wool slumped in the drought ravaged and depressed 1890s, Western Australia strengthened its creditworthiness and ability to channel revenue into agricultural development. Importantly, the Colonial government was determined to create an 'economic backstop' should the deposits of gold run out. Indeed, the belief that gold might only be a temporary source of prosperity, and that agriculture would provide a more permanent economic base, was reflected in a speech by Sir John Forrest in 1896:

"Who would not leave the plough to shovel for a time? But all that would come to an end... and those engaged in gold mining when they made money out of it would settle down and become permanent settlers on the lands of the colony" (quoted in Crowley, 2000, p.151).

To ensure the continuing expansion of agriculture the Western Australian government used the Colony's improved economic standing to finance the construction of a railway linking the goldfields and Perth. While improving the accessibility of the goldfields, the railway enabled farmers to transport grain and wool to the Colony's major port in Fremantle. The government also purchased the troubled Great Southern Railway, and associated lands, from the Western Australian Land Company under the Agricultural Lands Purchase Act, 1896. This Act also empowered the Lands Department to purchase large private estates, which had tended to remain undeveloped and in the hands of absentee landowners as speculative investments. Following their re-purchase by the Lands Department, these estates were generally subdivided into 160 acre lots for selection under the Homesteads Act.

By the late 1890s, however, it had become increasingly evident that, despite considerable state assistance, many farms were too small to remain economically viable (Greble, 1979). The subsequent Land Act, 1898, began to address this problem 
by enabling any person over the age of eighteen to apply for a surveyed block of agricultural land of up to 1,000 acres. This land was sold under conditional terms of purchase for at least ten shillings an acre, depending on the quality and attractiveness of the land. The conditions of purchase included clearing the natural vegetation, fencing the property, and undertaking other capital works to the value of the purchase price. To monitor the progress of individual farmers, the government appointed local Agricultural Bank officers to conduct regular farm inspections. The Act provided settlers with four clearly defined options for developing agricultural land: (i) A free grant of 160 acres under the Homesteads Act, 1893; (ii) Deferred payment with residence on the property; (iii) Deferred payment without residence on the property; (iv) Direct payment. The declining economic situation on the goldfields during the 1890s, together with the provisions of the Land Act, induced an increasing number of gold miners to take up land in the south-west of Western Australia.

Following Australian Federation in 1901, the new State Government of Western Australia continued with its aggressive agricultural development policies. The focus, however, remained on establishing a system of yeoman farming. In part, the continued pursuit of this ideal was fuelled by the early success of both the Agricultural Bank and the Land Act, 1898. It had also become clear that the expansion of small-scale agriculture had been in the form of ribbon development along existing railway lines. As a means of promoting further agricultural expansion a Royal Commission on Immigration and Land Settlement in 1905 (p.9) recommended the construction of a system of pioneer railways in those areas with "potential for the development of yeoman farming". The report of the Royal Commission became the basis for Western Australia's railway policy from 1906 and 
complemented existing agricultural development policies. The basic aim of the policy was to construct a network of low cost agricultural railways, thirty to forty miles (ca. $48 \mathrm{~km}$ to $64 \mathrm{~km}$ ) apart, thereby extending intensive agriculture into undeveloped areas. Accordingly, between Federation in 1901 and the onset of the First World War more than 4,000 kilometres of railway were constructed in agricultural areas (Glynn, 1975). The construction of railways and the existing agricultural development policies had a major impact on the area of land that under farming. Between 1901 and 1914, the area of agricultural land that had been, or was in the process of being alienated increased from $2,713,912$ hectares to $8,767,824$ hectares; a rise of 223.1 percent (Western Australia, 1901; 1914). However, in financing the construction of a landscape based on small-scale agriculture, public borrowings increased from A£7.1 million to a little more than A£16.9 million between 1901 and 1914 (Western Australia, 1901; 1914).

In the years leading up to the First World War, the Western Australian government promoted its agricultural development program heavily in eastern States and British newspapers. The following appeared in the The Australasian in 1909:

"...droughts unknown, seasons as certain as the sunrise...State Agricultural Bank the most liberal in the world...every acre served by existing railways, railways under construction, or proposed railways".

While advertisements like these were misleading, particularly in terms of the climate, the land was very cheap, and the state through its financial aid and infrastructure provisions did provide genuine incentives to potential small-scale farmers. The imagery associated with government advertising also continued to emphasise the yeoman ideal. Figure 2 is an example of an advertisement placed in the Western Mail newspaper in 1912. In addition to outlining the numerous development incentives 
available to prospective farmers, the advertisement states that "Napoleon Bonaparte's ideal of each individual being his own landlord still fascinates, and the Nation's prosperity may be gauged by such a policy". Another government advertisement from the same era quotes Jonathan Swift, author of Gulliver's Travels:

"Whoever could make two ears of corn or two blades of grass to grow upon a spot of ground where only one grew before would deserve better of mankind and do more essential service to this country than the whole race of politicians put together" (The Western Mail, 16/4/1913).

In many respects, the type of imagery that these advertisements presented was a direct reflection of the Western Australian government's ongoing desire to establish an agricultural landscape based on small-scale 'yeoman' farming in the years immediately prior to the onset of the First World War.

Insert Figure 2

\section{Conclusion}

By the start of the First World War, an increasing number of small farmers in Western Australia were facing serious economic hardship. A prolonged drought, together with deteriorating commodity prices, re-emphasised the need for greater economies of scale than those available on the parcels of land that were provided under existing land legislation. As the 1917 Royal Commission on Agriculture pointed out, the small size of farms, together with the ongoing mechanisation of farms, had contributed to a situation were landholders were being forced to 'get big or get out' of agriculture. The outcome was an ongoing process of farm amalgamation and enlargement. In many respects, the small-scale yeoman farmer had become an 
economic inefficiency in an increasingly profit driven agricultural landscape (Snooks, 1974). While the yeoman ideal gradually disappeared from the policy environment and rhetoric, it remained an important element of Australian society and mythology (Carroll, 1992). As Lockie (2000) points out, constructions of Australian identity continue to present the nation's farmers as hard working and self reliant in their battle against the elements and economic forces. It was this image, together with an aspiration for the development of a landscape based on small-scale cultivated agriculture, that played such a critical role in early Western Australian agricultural policy. 


\section{WESTERN AUSTRALIA, \\ THE LAND OF GOLDEN OPPORTUNITY EMIGRAITSS. F FMIGRAITS. EXCEPTIONAL FACILITIES OFFERED. \\ VAST AND FERTIIE TERRITORY. \\ There is a tide in the aftairs of men, which, taken at the flood, leads on to fortune." - Shakespeare. \\ Napoleon Bonaparte's Ideal of each Indlvidual being hls own LANDLORD still faseinates, and the Nation \\ AVOID THE VISIONARY, BUT DO NOT NEQLECT SOLID FACTS. \\ OUR ENTENTE CORDIALE EXTENDS TO DESIRABLE SETTLERS. \\ CHEAP LAND \\ ON MOST \\ LIBERAL CONDITIONS.}

160 ACRES A8 A HOMEBTEAD FARM FOR \&1. NO RENT.

1,000 Aoros undor REsIDENGE, from 102. por aore upwarde, 20 years' torms for payment. A furthor 1,000 Mores undor MON-REsiDENGE Conditions at similiar ratee.

GRNZIME LAMDs at from 3e. 9d. per aore.

QARDEW BLOCKS of from 5 to 50 Nores, at 21 per acre, payable in throe yeare.

EASY CONDITIONS OF IMPROVEMENT.

half cost of survey paId BY state.

FEE SIMPLE granted if all conditions are complied with.

AGRICULTURAL RAILWAYS being extended in every direotion.

AGRICULTURAL BANK ADVANCES LOANS

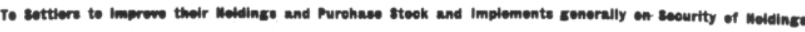

EABY RATE8 OF INTEREST AND LONG TERM8.

Suro Raintall and Excellent Cllmate. Natural Orasses and Splendid Fodder Plants abound. Imported Orasses thrive.
Magnificent Markets for all classes of Agricultural Produce.

IMPORTS IN EXCESS OF LOCAL PRODUCTION DURING ONE YEAR, OVER \&1.564.000

\section{ASSISTED PASSAGES TO EMIGRANTS.}

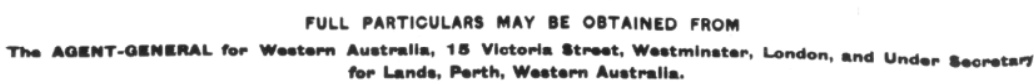

(Source: Murphy and Nile, 1990)

Figure 2 Government Advertisement for Prospective Settlers in Western Australia, 1912 


\section{Bibliography}

Appleyard, R. T. (1981) Western Australia: economic and demographic growth, 1850-1914, in: Stannage, C. T. (Ed.) A New History of Western Australia, pp. 211236 (Nedlands, University of Western Australia Press).

Battye, J. S. (1924) Western Australia: A History from its Discovery to the Inauguration of the Commonwealth (Oxford, The Clarendon Press).

Benedict, M. (1953) Farm Policies of the United States, 1790-1950 (New York, Twentieth Century Fund).

Bolton, G. C. (1958) Alexander Forrest: His Life and Times (Nedlands, University of Western Australia Press).

Bolton, G. C. (1972) A Fine Country to Starve In (Nedlands, University of Western Australia Press).

Burvill, G. H. (1979) Agriculture in Western Australia (Nedlands, University of Western Australia Press)

Cameron, J. M. R. (1975) The Colonisation of Pre-Convict Western Australia, Unpublished PhD Thesis (Perth, University of Western Australia). 
Cameron, J. M. R. (1981) Ambition's Fire: The Agricultural Colonisation of PreConvict Western Australia (Nedlands, University of Western Australia Press).

Cochrane, W. W. (1993) The Development of American Agriculture: A Historical Analysis (Minneapolis, University of Minnesota Press).

Commission on Agriculture. (1891) Final Report of the Commission on Agriculture, in: Votes and Proceedings of the Western Australian Parliament, Part XII. (Perth, Government Printer).

Commonwealth of Australia. (1921) Historical Records of Australia, Series III: Despatches and Papers Relating to the Settlement of the States (Sydney, Library Committee of the Commonwealth Parliament).

Cooper, W. S. (1975) The Historical Geography of the Agricultural Areas Along the Perth-Bunbury and Bunbury-Bridgetown Railways, 1890-1918, Unpublished MA Thesis (Perth, University of Western Australia).

Crowley, F. K. (1960) Australia's Western Third (Nedlands, University of Western Australia Press).

Crowley, F. K. (2000) Big John Forrest: A Founding Father of the Commonwealth of Australia (Nedlands, University of Western Australia Press).

Eggleston, F. (1932) State Socialism in Victoria (London, P. S. King and Sons). 
Fite, G. C. (1981) American Farmers: The New Minority (Bloomington, Indiana University Press).

Glynn, S. (1966) Private enterprise and public policy: an Australian land grant railway, University Studies in History, 4, pp. 41-61.

Glynn, S. (1975) Government Policy and Agricultural Development: A Study of the Role of Government in the Development of the Western Australian Wheatbelt (Nedlands, University of Western Australia).

Greble, W. E. (1979) A Bold Yeomanry: Social Change in A Wheat Belt District (Perth, Creative Research).

Hasluck, A. (1965) Thomas Peel of Swan River (Melbourne, Oxford University Press).

Hibbard, B. H. (1939) The History of Public Land Policies (New York. Peter Smith).

Lockie, S. (2000) Crisis and conflict: shifting discourses of rural and regional Australia, in: Pritchard, W. and McManus, P. (Eds.) Land of Discontent: The Dynamics of Change in Rural and Regional Australia, pp. 14-32 (Sydney: University of New South Wales Press). 
Metin, A. (1901) Le Socialisme sans Doctrines: La Question Agraire et la Question Ourvriere en Australie et Novelle-Zealande (Paris, Felix Alcan).

McMichael, P. (1984) Settlers and the Agrarian Question: Foundations of Capitalism in Colonial Australia (Cambridge, Cambridge University Press).

Murphy, F. and Nile, R. (1990) The Gate of Dreams: The Western Mail Annuals, 1897-1955 (Fremantle, Fremantle Arts Centre Press).

Paarlberg, D. (1964) American Farm Policy (New York, John Wiley and Sons).

Parliamentary Debates of Western Australia (PDWA)(1886)(Perth, Government Printer).

Parliamentary Debates of Western Australia (PDWA)(1893)(Perth, Government Printer).

Parliamentary Debates of Western Australia (PDWA)(1896)(Perth, Government Printer).

Powell, J. M. (1988a) The Historical Geography of Australia: The Restive Fringe (Cambridge, Cambridge University Press).

Powell, J. M. (1988b) Patrimony of the people: the role of government in land settlement, in: Heathcote, R. L. (Ed.) The Australian Experience: Essays in Australian 
Land Settlement and Resource Development, pp. 14-24 (Melbourne, Longman Cheshire).

Roberts, S. H. (1924) History of Australian Land Settlement (Melbourne, Melbourne University Press).

Snooks, G. D. (1974) Depression and Recovery in Western Australia, 1928/291938/39: A Study in Cyclical and Structural Change (Nedlands, University of Western Australia Press).

Votes and Proceedings of the Legislative Council (1884)(Perth, Government Printer).

Western Australia. (1901) Statistical Register of Western Australia, 1901 (Perth, Government Printer).

Western Australia (1914) Statistical Register of Western Australia, 1914 (Perth, Government Printer). 